\title{
THE HUMAN BODY'S HYDRAULICS
}

\author{
Florian Ion Tiberiu Petrescu \\ IFToMM, Romania \\ E-mail: fitpetrescu@gmail.com \\ Relly Victoria Virgil Petrescu \\ IFToMM, Romania \\ E-mail: rvvpetrescu@gmail.com
}

Submission: $12 / 13 / 2018$

Accept: 12/19/2018

\section{ABSTRACT}

This paper presents some aspects related to the human body's hydraulics in the desire to make readers aware of how to maintain all the blood vessels of the human body in order to maintain the entire healthy, functional, young, vigorous circulatory system for a while the longest possible. The problem is complex because it has to be viewed from all points of view and not only as an isolated system in the body, having aspects of fitback on the whole physiopathology belonging to the human body. The highly circulating system needs permanent maintenance. Selfmaintenance is done through various physiological mechanisms tightly linked to each other, including the lymphatic, digestive, renal, lung, nervous, glandular system ... It is not possible to completely separate the physiology of a system from the other adjacent systems because they all work synergistically, being permanently controlled by the central and peripheral nervous system.

Keywords: Human body; Human body's hydraulics; Blood vessels; Physiopathology; Anti aging 
DOI: 10.14807/ijmp.v10i6.932

\section{INTRODUCTION}

This paper presents some aspects related to the human body's hydraulics in the desire to make readers aware of how to maintain all the blood vessels of the human body in order to maintain the entire healthy, functional, young, vigorous circulatory system for a while the longest possible.

The problem is complex because it has to be viewed from all points of view and not only as an isolated system in the body, having aspects of fitback on the whole physiopathology belonging to the human body.

The highly circulating system needs permanent maintenance. Selfmaintenance is done through various physiological mechanisms tightly linked to each other, including the lymphatic, digestive, renal, lung, nervous, glandular system ... It is not possible to completely separate the physiology of a system from the other adjacent systems because they all work synergistically, being permanently controlled by the central and peripheral nervous system.

The biggest problems with the old hydraulic systems were maintenance and operation, because there was always something in the system was blocking somewhere so the whole system stops or works badly.

Even today, it is not easy to maintain a hydraulic system whose circuits have quite large lengths measured in meters.

Then how difficult should it be to maintain the human body's hydraulic system that measures about 100,000 kilometers in length?

And not for a few hours or days or years, but for a minimum of 100 years, although it may well be as good for 150 years. In fact, just maintaining this functional system for a longer time will prolong the life of the body consistently, this system being very demanding and vital for the human body as well.

By the way we maintain the blood vessels of our body depends on his health and his life.

The cardiovascular / circulatory system is a device that allows the circulation of blood and lymph in the body to transport nutrients, oxygen, carbon dioxide, etc. It consists of heart and blood vessels, arteries, veins, and capillaries that are spread across a dense network throughout the body (Figure 1). 
ISSN: 2236-269X

DOI: 10.14807/ijmp.v10i6.932

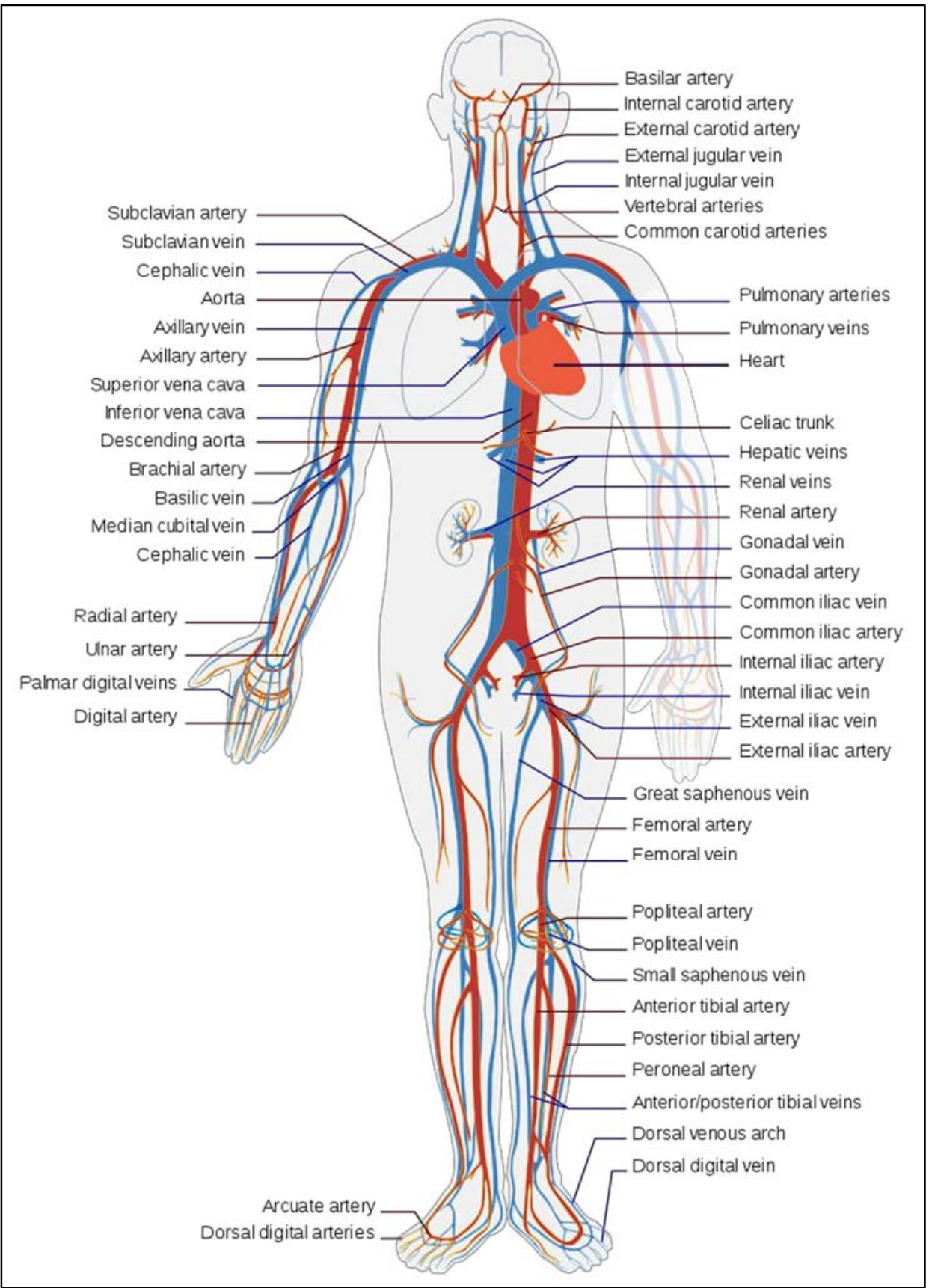

Figure 1: Simplified diagram of the human Circulatory system.

Source: https://en.wikipedia.org/wiki/Circulatory_system\#/media/File:Circulatory_System_en.svg

The heart, weighing 350 grams per adult, has the shape of a cone with the tip pointing down, and the base corresponds to the large vessels (CAVAL VEINS et al., 2018).

It is a muscular organ whose walls have four layers: the pericardium - the fibrous sac in which the heart, the myocardium (the heart muscle) is housed inside the endocard, and on the outside by a serous membrane, the epicardium.

The heart pump has four chambers: the right and left atrium (or right or left ear) 
with the thin walls - the receiving chambers - and the right and left ventricles with the thicker walls representing the actual pump (Figure 2).

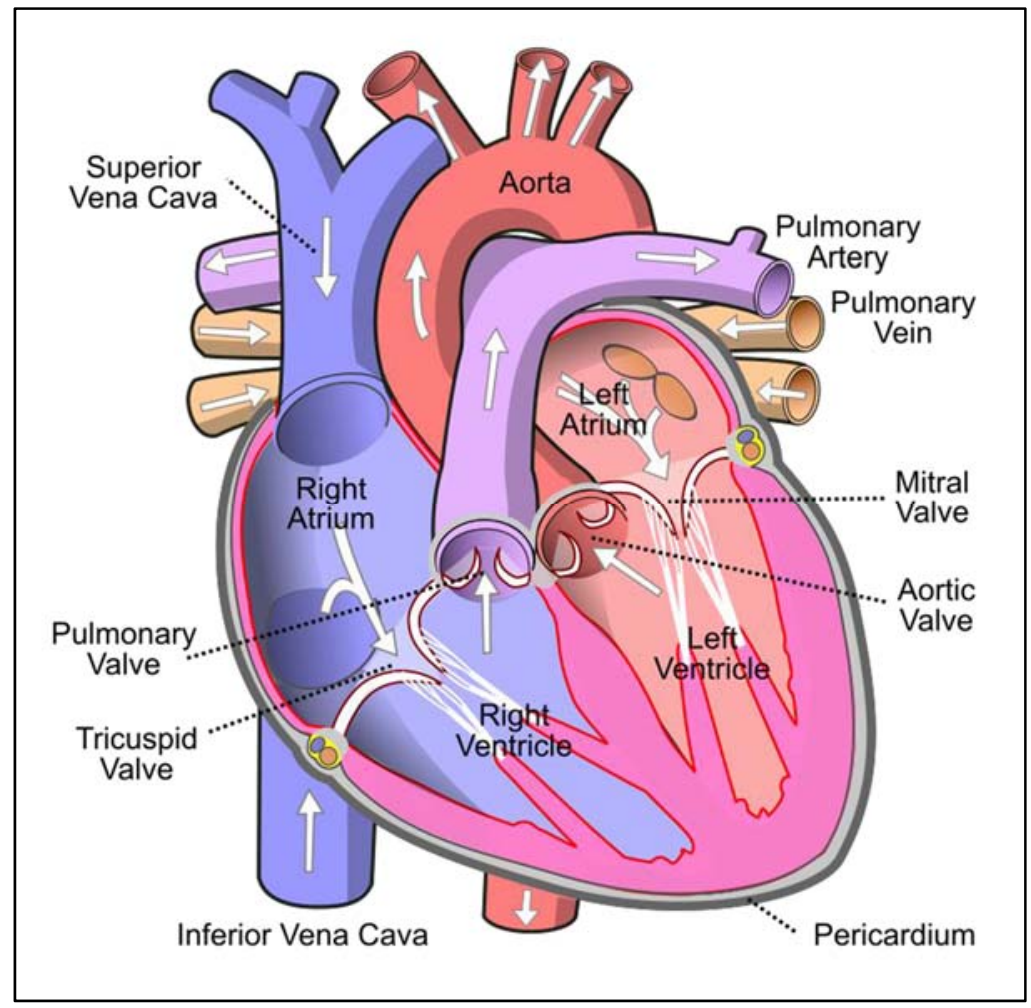

Figure 2: Diagram of the human heart 1. Superior Vena Cava 2. 4. Mitral Valve 5. Aortic Valve 6. Left Ventricle 7. Right Ventricle 8. Left Atrium 9. Right Atrium 10.

Aorta 11. Pulmonary Valve 12. Tricuspid Valve 13. Inferior Vena Cava.

Source: https://en.wikipedia.org/wiki/Circulatory_system\#/media/File:Diagram_of_the_human_

$$
\text { heart_(cropped).svg }
$$

Between the cavities there are communication holes, namely: between the atrium and the left ventricle - the mitral valve, between the atrium and the ventricle as the tricuspid valve; of the left ventricle comes out with the aortic valve aorta, and the right ventricle exits the pulmonary artery with its valve. Well functioning of the valves helps the blood filling of the heart during the resting period (diastole) and its propulsion after contraction (systole) in the sea and the small circulation.

The heart is the only muscular organ that rhythmically contracts, without interruption, from embryonic life to death.

Cardiac automatism is provided by a specialized center (the sinus node located in the right atrium), from which the heart stimulus starts and from where it is transmitted further from the atrioventricular node (located in the inter-atrial septum), then from the His beam (from the interventricular septum ) and the purkinje network (from the ventricular walls whose electrical activity gives positive and negative 
DOI: 10.14807/ijmp.v10i6.932

waves on the electrocardiogram (abbreviated ECG)).

The arteries represent the largest blood vessels. They have the role of transporting oxygenated blood from the heart to tissues and organs.

The drawings are represented in red. The artery is composed of three layers: the outer tunic, the muscular tunic (middle tunic) and the inner tunic.

External tunic is made up of connective tissue with collagen and elastin fibers, as well as vegetative nerve fibers and blood vessels providing oxygen for the vascular wall. Medium or medium tunica consists of smooth muscle cells and elastic connective fibers. Internal tunica (also called vascular endothelium) is a simple pavimental epithelium found on a basal membrane and an elastic subendothelial layer.

The arteries have the highest pressure due to the constant flow of blood pumped by the heart.

The veins are responsible for transporting the deoxygenated blood from the tissues, organs back to the heart. Unlike the arteries, the boundary between the tunics is not uniform.

The internal tunica below the heart level has dovetail-shaped valves, called half- moon, that guide the blood flow; when the blood starts in the right direction, the valves remain open due to cone-shaped positioning. If the blood wants to take it back, they close because of pressure. They are present because there is nothing that pumps the blood back, so he can take it in any direction. Medium tunica is thinner, while the outer one is thicker.

Capillaries are the smallest blood vessels, reaching even a diameter of two or three cells $(15-20 \mu \mathrm{m})$. Because of their size they can reach anywhere in the body. The oldest capillary network is found on the lung alveoli.

The capillaries result from the ramification of the meta-cartels, continuing with the capillary veins; have $0.5 \mathrm{~mm}$ long. The more metabolic the metabolic activity of the tissue, the more capillaries are present.

Exchanges of gases and other substances are carried out by diffusion and filtration.

Blood pumping is done with the myocardium. When it contracts, the blood 
passes from the ventricles into the pulmonary arteries, respectively in the aorta, the stage being called systole. After contracting, the diastole follows, where the blood enters the atria in the upper and lower cavity veins and in the pulmonary veins, and then in the ventricles.

Circulation is represented by two stages: diastole and systole. They influence blood pressure and heart noises.

The diastole, also called the small circulation, is the passage of blood into the atria in the upper and lower cavity veins (right atrium) and the pulmonary veins (left atrium) and then into the respective ventricles. At this stage the blood pressure is the lowest.

Systole, also called large circulation, represents the passage of blood from the ventricles into the pulmonary arteries (right ventricle) and the aorta (left ventricle). This is done by contraction of the heart muscle. At this stage the blood pressure is highest. Here is also the specific beating of the heart.

The circulatory system of the lungs is the portion of the cardiovascular system in which oxygen-depleted blood is pumped away from the heart, via the pulmonary artery, to the lungs and returned, oxygenated, to the heart via the pulmonary vein.

Oxygen deprived blood of the superior and inferior vena cava enters the right atrium of the heart and flows through the tricuspid valve (right atrioventricular valve) into the right ventricle, from which it is then pumped through the pulmonary semilunar valve into the pulmonary artery to the lungs. Gas exchange occurs in the lungs, whereby $\mathrm{CO} 2$ is released from the blood, and oxygen is absorbed. The pulmonary vein returns the now oxygen-rich blood to the left atrium.

A separate system known as the bronchial circulation supplies blood to the tissue of the larger airways of the lung (Figure 3 ). 
DOI: 10.14807/ijmp.v10i6.932

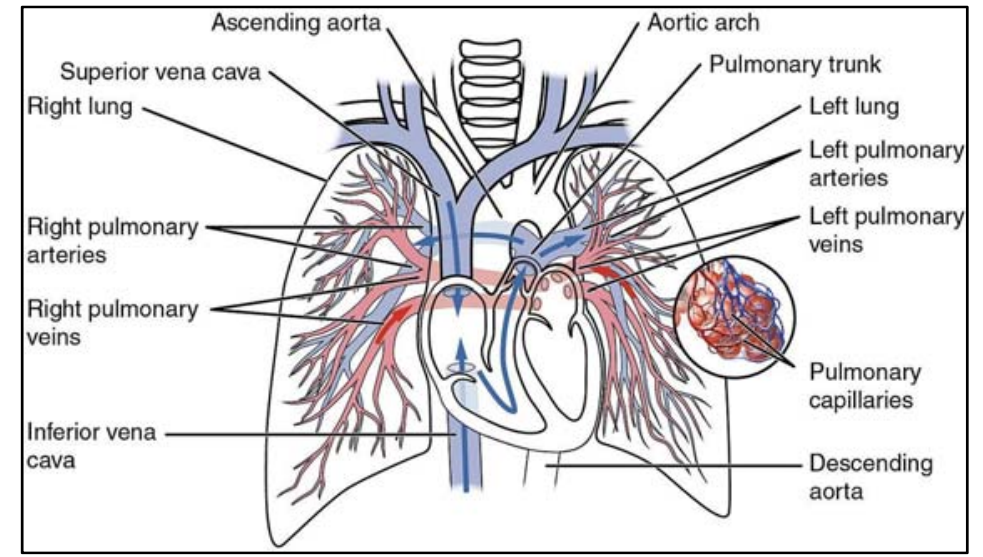

Figure 3: The pulmonary circulation as it passes from the heart. Showing both the pulmonary and bronchial arteries.

Source: https://en.wikipedia.org/wiki/Circulatory_system\#/media/File:2119_Pulmonary_Circuit.jpg

The brain has a dual blood supply that comes from arteries at its front and back. These are called the "anterior" and "posterior" circulation respectively. The anterior circulation arises from the internal carotid arteries and supplies the front of the brain. The posterior circulation arises from the vertebral arteries and supplies the back of the brain and brainstem.

The circulation from the front and the back join together (anastomise) at the Circle of Willis.

The renal circulation receives around $20 \%$ of the cardiac output. It branches from the abdominal aorta and returns blood to the ascending vena cava. It is the blood supply to the kidneys and contains many specialized blood vessels.

The lymphatic system is part of the circulatory system. It is a network of lymphatic vessels and lymph capillaries, lymph nodes and organs, and lymphatic tissues and circulating lymph. One of its major functions is to carry the lymph, draining and returning interstitial fluid back towards the heart for the return to the cardiovascular system, by emptying into the lymphatic ducts. Its other main function is in the adaptive immune system (AVERSA et al., 2018a; AVERSA et al., 2018b; AVERSA et al., 2017a; AVERSA et al., 2017b, AVERSA et al., 2016a; AVERSA et al., 2016b; AVERSA et al., 2016c; AVERSA et al., 2016d; AVERSA et al., 2016e; AVERSA et al., 2016f; AVERSA et al., 2016g; AVERSA et al., 2016h; AVERSA et al., 2016i; AVERSA et al., 2016j; AVERSA et al., 2016k; AVERSA et al., 2016l; AVERSA et al., 2016m; AVERSA et al., 2016n; ALJOHANI; DESAl, 2018; ALEXANDER; WANG, 2018; APICELLA et al., 2018a; APICELLA et al., 2018b; APICELLA et al., 2018c; MARQUETTI; DESAI, 2018; ARMAH, 2018; WILK et al., 
2017).

The innervation of the vessels is accomplished through a sympathetic nerve fiber network that is also called vasomotor nerves and forms nerves called vascularis. Nerve fibers are more numerous in the veins than in the arteries. The related nerve terminations of the arterial level can be classified into baroreceptors and chemoreceptors. Baroreceptors can be identified at the level of: Carotid sinus, located immediately under the bifurcation of the primary carotid, and the nerve endings come from nerve $\mathrm{XI}$; Aortic arch.

The chemoreceptors can be identified at the level of: Carotid Corpus, located at the level of the carotid bifurcation, and consists of two types of glom cell; The aortic cortex, which is located between the sub clavicular and the right carotid, on the right and near the left sub clavicula on the left.

\section{METHODS AND MATERIALS}

As has already been said, this highly circulating system needs permanent maintenance. Self-maintenance is done through various physiological mechanisms tightly linked to each other, including the lymphatic, digestive, renal, lung, nervous, glandular system ... It is not possible to completely separate the physiology of a system from the other adjacent systems because they all work synergistically, being permanently controlled by the central and peripheral nervous system.

For this reason, and the pathophysiology of the renal system will be briefly presented.

We are made of water, almost $65 \%$ of everything we stand for as human beings are water. We are born of water which then gradually lose as we get older.

This explains that a human embryo is $97 \%$ water, at birth the newborn is made up of $90 \%$ water, toddler contains $80 \%$ water, the same child at school age will have a $70 \%$ water, following that in adulthood to remain only $60-65 \%$ water by weight.

The percentage of water also differ by gender and body fat percentage. So that women have a higher percentage of fat (placed in the hands, hips and the cellular tissue subcutaneous fat) than men, they will average $5 \%$ less water than men of the same age. This is because fat tissue has the ability to retain a very small amount of water, which explains the reduction of the body's water content. 
INDEPENDENT JOURNAL OF MANAGEMENT \& PRODUCTION (IJM\&P)

http://Www.ijmp.jor.br

v. 10, n. 6, November - December 2019

ISSN: 2236-269X

DOI: 10.14807/ijmp.v10i6.932

Water is the medium which holds all biological and chemical reactions in the body, resulting in the production of heat and energy metabolism reactions that required life support.

For these reactions can take place is necessary that substances to be dissolved in water, otherwise they can not pry into ions and reactions cannot occur.

The water is in the composition of all organs and helps them perform their functions.

Blood contains $90 \%$ water, muscles $75 \%$, $83 \%$ brain, lungs $86 \%, 83 \%$ kidneys, eyes $95 \%, 22 \%$ bones. Kidneys need water in order to filter the blood, digestive needs water for digestion, skin needs water to keep smooth and healthy, and bones to maintain elasticity and strength (BABAEV et al., 2010).

Water circulates through the blood and lymph oxygen and nutrients to the organs. Water helps remove metabolic waste by the kidneys, which is impossible in the absence of a quantity of water acting as a conductor.

Water participates in the formation and the growth of cells of the body. The water helps in maintaining a constant body temperature by making the body thermoregulation.

When the body is overheated (summer or in fever) water removes heat which abound through perspiration, and in winter when the body suffers from cold, water adapts the body to keep warm blood around vital organs, causing capillaries to contract to save water losses (BUZEA et al., 2015; PETRESCU et al., 2015).

The main source of energy of living matter is made in molecules known as ATP (Adenosine triphosphate).

An ATP molecule may change any sunlight heat to a form of energy which may be used by plants, humans, and animals.

An ATP molecule contains these four vital elements: oxygen, hydrogen, nitrogen, and phosphorus (thirteen oxygen atoms, eight hydrogen atoms, five nitrogen atoms, and three phosphorous atoms).

Of the 28 atoms of an energy molecule ATP, 20 are originating from the water. Practically is important how the atoms of the four elements are connected in an 
ATP molecule (Figure 4).

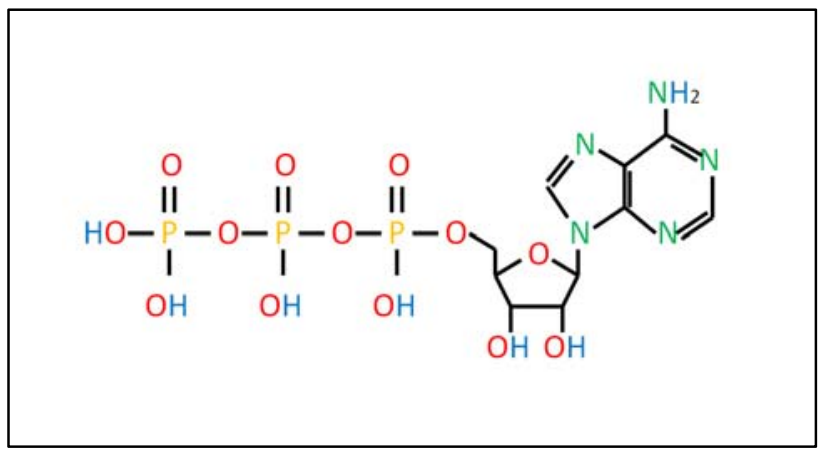

Figure 4: How the atoms of the four elements are connected on one ATP molecule

When water is present at the cellular level in small quantity, the cells (mitochondria) cannot produce enough energy. Then are decrease the number of energy molecules (ATP). The body is getting weaker (emaciated energy), aging, and death.

Water loss triggers thirst reflex (that means it has already begun the process of dehydration and body suffer). Sometimes that thirst not works (to be inhibited by factors such as age, hormonal disorders, or a chaotic lifestyle, but that does not mean that the body does not require hydration). In addition, dehydrated and tired brain refuses to send appropriate signals for thirst. Therefore it requires some water consumption calculated from time to time whether we are thirsty or not. A serious problem is the loss of water from cells (cellular water loss) with age.

Brain affected. British researchers found that dehydration causes shrinkage of brain size but it returns to normal immediately after consuming a few glasses of water. When we lose water affected the smooth functioning of the brain and nervous system, leading to the emergence of imbalances that we experienced as nervousness, irritability and anxiety, tiredness, exhaustion and inability to concentrate. Because a dehydrated brain can't think or process information correctly then are deducted intellectual performances, short-term memory is also impaired to a decrease of only $2 \%$ of body water.

When decreases the hydration level of the body, lungs slow down their activity thus limiting water loss through breathing. Appear difficulty in breathing and organs are not functioning properly oxygenated in damage (dizziness and general bad).

When the water is low in the body appears constipation and decreased 
INDEPENDENT JOURNAL OF MANAGEMENT \& PRODUCTION (IJM\&P)

http://Www.ijmp.jor.br

v. 10, n. 6, November-December 2019

ISSN: 2236-269X

DOI: 10.14807/ijmp.v10i6.932

urine output. Without water, feces become dry and hard, very difficult to eliminate (manifested by abdominal pain) and release of toxins into the bloodstream. Urine becomes too concentrated, dark and limited as of quantity, making kidneys to do not have enough water to remove metabolic wastes. This concentrated urine promotes the crystallizing of molecules of calcium, oxalate and uric acid, ie kidney stones.

As the water level drops in the body (dehydration or old age) comes the drying of the skin and mucous membranes. The skin loses its elasticity and firmness, get easy wrinkles and can exfoliate. The feeling of "dry mouth" look red and cracked lips, saliva becomes sticky. Vary the pressure in the eyeballs, eyes can't produce tears, appears the feeling of "sand in the eyes".

A headache can occur due to decreased oxygen flow to the brain and its poor irrigation. Dehydration could also be the cause of migraines. It has been shown that the best approach to a headache is to drink a glass of water of 10 in 10 minutes for an hour.

Fatigue after meals can occur when there is a deficiency of water in the body. If the digestion process starts on a background deficient water, the blood thickens and for the hydration process, it draws water from vital organs (that so they dehydrate) in order to achieve digestion, which explains why, after eating, we feel tired and flabby. If you drink a glass of water before a meal, digestion is without difficulty and we feel energized.

When the body is very dehydrated can no longer provide water to the blood circulation, case in which, may occur the state of shock, hallucinations, fainting condition that can culminate with coma and even death.

Approximately $2 / 3$ of the total water to a human body is located in the compartment intracellular (water that is kept as a reserve within every human cell).

A third is an extracellular water so apportioned: $20 \%$ extra vascular sector (Lymph and interstitial fluid) and $8 \%$ vascular sector (the water from blood).

Water flows freely and quickly between all these compartments in response to changes of the solvents concentrations, to maintaining the balance between compartments (osmosis).

In an adult of $70 \mathrm{~kg}$, water is of about $40 \mathrm{I}$, of which $25 \mathrm{I}$ is intracellular 
DOI: 10.14807/ijmp.v10i6.932

water, extracellular water $15 \mathrm{I}$; in the total plasma volume is typically 2.75 to $3 \mathrm{I}$. The water intravascular is at least $85 \%$ in the territory of the capillary and venous and arterial within $15 \%$. Of maintaining the volume of arterial water depends greatly on the arterial blood pressure, regulation of extracellular fluid volume, and retention of sodium and water.

Sodium is the main extracellular cation and the determining element of achieving an effective osmosis. The intracellular sodium concentration is an average of $15 \mathrm{mmol} / \mathrm{l}$ and the extracellular sodium $140 \mathrm{mmol} / \mathrm{l}$. The average daily intake of sodium is $100-200$ mmol. Sodium absorption occurs in the small intestine and colon. Body water (intra and extracellular) comes on one side of liquids and foods (1-4 I / day), and on the other side of the oxidation of lipids, carbohydrates and proteins (200-500 g water daily).

Water is eliminated nonrenal (loss of skin and respiratory) and kidney (via urine formation). These water losses have an essential role in the body to remove toxins that accumulate in the human body permanently (intra and extracellular). The volume of urine daily intake can equalize with the removal of water. Final urine is the result of filtering of the plasmatic water (levels $180 \mathrm{l} /$ day) and reabsorption (99\% of the filtered water is reabsorbed into the renal tubule, of which approximately $66 \%$ is reabsorbed in the proximal convoluted tubule, iso-osmotic, non-adjustable; reabsorption adjustable occurs in the collector tube, cortically and medullary). Urine is only $1 \%$ of the filtered water (1-2 liters/day). Water losses (skin and respiratory) are $650-850 \mathrm{ml} /$ day.

So, about a third of water with toxins is eliminating through the skin. In addition, the skin breathes like the nostrils, so it is necessary not only maintaining skin cleanliness but and its integrity (no burns or tattoos). Sodium is the main extracellular cation, representing the most important force osmotic which maintains the size of the extracellular fluid volume.

Increasing the total amount of sodium in extracellular fluid is followed by an increased volume of the extracellular fluid compartment thereof and its overcharging. Increase blood pressure. Syndromes of swelling (in congestive heart failure, liver cirrhosis, nephrotic syndrome) are medical conditions with the increased amount of sodium in the extracellular compartment (ABDUL-RAZZAK 
et al., 2012; AJITH et al., 2009; ATASAYAR et al., 2009).

If the total amount of sodium in the extracellular compartment decreases, the volume decreases and resulting depletion of the extracellular compartment volume (extracellular dehydration). In this case, the water supply decreases and from the blood, resulting in disorders of the entire body. In case of a decrease in the volume of the sector plasma, it can observe the acceleration in heart rate, decreased blood pressure in lying or standing, pale skin and cool extremities, decreased urine output, flattening the neck and forearm veins, the blood pressure occlusion. In case of loss of more than $30 \%$ of plasma volume, occurs the hypovolemic shock with cyanosis of extremities and neurological signs of cerebral hypoperfusion (drowsiness, confusion, agitation).

Keeping the decrease of the volume of extracellular salt and water (much) longer produces an excessive consumption from the intracellular water reserves. It also produces and decreased interstitial fluid volume. An interstitial sector is partly responsible for skin elasticity and firmness. Such skin aging occurs and of the cells. With the loss of water from the cells and energy is lost. Without enough water in cells are produced fewer ATP molecules (even if we have enough mitochondria). Cell aging occurs and a lack of energy.

Conversely, in the event of increased plasma sector, there is an increase in blood pressure.

All processes of a human body are and finely controlled by the various hormones produced by glands. In this respect, it is important to know as well as physio- pathology of various human processes. That happens and with retention or release of sodium and water.

Renin is an enzyme formed and released by the granule cells of the glomus (AHMED et al., 2011). Renin catalyzes the conversion of angiotensinogen (protein synthesized by the liver) to angiotensin I. Angiotensin I is converted by a converting enzyme into angiotensin II, which is biologically active (COVIC et al., 2007).

Angiotensin II promotes salt retention through direct and indirect effects. It directly stimulates sodium reabsorption in the proximal tubule (by stimulating the exchange $\mathrm{Na}+/ \mathrm{H}+)$. Indirectly, it affects sodium balance by stimulating the 
INDEPENDENT JOURNAL OF MANAGEMENT \& PRODUCTION (IJM\&P)

http://Www.ijmp.jor.br

v. 10, n. 6, November - December 2019

ISSN: 2236-269X

DOI: 10.14807/ijmp.v10i6.932

production and release of aldosterone from the glomerular zone of the adrenal. Aldosterone induces a sodium reabsorption (and $\mathrm{K}+$ secretion) in the distal convoluted tubule and sewer.

Vasopressin or antidiuretic hormone is regulated primarily by the osmolarity of body fluids, but the vasopressin increases and in volume-depleted states. This promotes water retention and restoration of body fluid volume.

The atrial natriuretic factor is a peptide synthesized by atrial myocytes and released as a response to atrial distension. It is effective to increase natriuresis by the action of vasodilating the afferent arteriole with increasing DFG (glomerular filtration flow) and filtered soda task; It has a direct inhibitory action on the absorption of soda in the proximal tubule and medullary tube collector. It has an inhibitory effect on renin release, ADH (antidiuretic hormone) and aldosterone.

Prostaglandins have vasodilating renal action and induce the removal of sodium and water. They increase the excretion of sodium by increasing the amount of sodium filtered. And all they increase water excretion by antagonizing $\mathrm{ADH}$.

The sympathetic nervous system, the renin-angiotensin-aldosterone system, the natriuretic peptide atrial and the vasopressin represent the four main systems regulators who tailor their activity in response to changes in body fluid volume.

All processes of a human body are and finely controlled by the various hormones produced by glands. In this respect, it is important to know as well as physio- pathology of various human processes. That happens and with retention or release of sodium and water.

The sympathetic nervous system, the renin-angiotensin-aldosterone system, the natriuretic peptide atrial and the vasopressin represent the four main systems regulators who tailor their activity in response to changes in body fluid volume.

Keeping the decrease of the volume of extracellular salt and water (much) longer produces an excessive consumption from the intracellular water reserves. It also produces and decreased interstitial fluid volume. The interstitial sector is partly responsible for skin elasticity and firmness. Such skin aging occurs and of the cells. With the loss of water from the cells and energy is lost. Without enough water in cells are produced fewer ATP molecules (even if we have enough mitochondria). Cell 
DOI: 10.14807/ijmp.v10i6.932

aging occurs and a lack of energy.

Conversely, in the event of increased plasma sector, there is an increase in blood pressure.

Kidney health depends directly on the health of the entire body. Their illness leads to illness and aging of the body. If we can solve these problems the human life could be extended to 100,150 or 200 years. Some experts say that human aging starts right from its birth. We believe that aging is genetically programmed, but she begins with the moment when the body stops from growing.

Because the most important essential cure for maintaining the body, but especially for the circulatory and renal apparatus, the heart and the brain, together with the central and peripheral nervous system, is vitamin $C$, that vitamin will be presented now.

If one consider the statistics established by WHO regarding the annual deaths caused by coronary artery disease, since the discovery made by Canadian researchers in the 50s until today, were billion earthlings which died of cardiovascular disease, that could be cured with vitamin $\mathrm{C}$, if mankind could have benefited by the experimental results of Canadian researchers team. Deaths from heart disease (caused by chronic scurvy) could be avoided by a simple treatment with vitamin C (WILLIS, 1953; WILLIS, 1954; WILLIS, 1957). What is not told to the patients is the fact that open heart surgery fails in $40-50 \%$ proportion of cases, since the disease soon recurs after surgery. Solving the safest and effective known heart disease, it consists of daily administration of a dose of 6000 to $10,000 \mathrm{mg}$ vitamin C (ABDUL-RAZZAK, 2012; AHMED, 2011; AJITH, 2009; ATASAYAR, 2009; BABAEV, 2010; BUZEA, 2015).

It was known long ago that vitamin $\mathrm{C}$ deficiency in the body weakens human arteries by forming atherosclerotic plaques (infiltration of the walls of the aorta and arteries with fat), which blocks blood circulation. Dr. Pauling and his team found that upon submission of atheromatous plaques within the arteries, often occurs rupture of a weakened artery and resulting blood clots that lead to heart attack or stroke. Scurvy chronic responsible for heart disease, it was confirmed by cardioretinometry and was healed by daily doses of vitamin C, by Dr. Sidney Bush, from the UK. Dr. Sidney Bush noted that building plagues are reduced and 
DOI: 10.14807/ijmp.v10i6.932

disappear following daily doses of up to $10,000 \mathrm{mg}$ vitamin C. Based on these observations he developed a new method of diagnosing coronary disease, called cardioretinometry.

Pericorneal vascularization demonstrates that all people are affected at some point by scurvy, most of them suffering from this condition all the time. Chronic subclinical form, unknown widely, can be diagnosed using sequential electronic retinal arterial images and cured by varying amounts of vitamin C associated with some nutrients.

Free Radicals meet many critical functions in our body, checking blood passing through the artery up to the fight against infection. Some free radical signal molecules that are responsible for starting and stopping of genes. Some free radicals, such as nitric oxide and superoxide, are produced in large quantities by our cells immune to "poison" viruses and bacteria. However in less than a second, free radical may turn against us, we may sicken and we can grow old too fast. Where there is a stroke or a heart attack, or just an inflammatory disease such as arthritis, free radicals are existing or in production.

For us to understand what are free radicals must be known human cells, where every day, and every second, is wearing a war between free radicals and antioxidants. Like anything in the universe, and the cells are made up from smaller units called atoms. Each atom contains a nucleus that is surrounded by electrons. Two or more atoms may be linked by dividing electrons forming molecules. The biological process of oxidation (the process of training of energy), involve the transfer of electrons from an oxygen molecule to the next.

For these reasons sometimes may escape one lone electron. An atom remained without one electron (an ion) present in the human body, bears the name of a free radical. Free radicals are formed constantly almost everywhere in the body in an amazing proportion. If free radicals spread by all over the body are not caught, may attack and oxidize DNA, the genetic material that controls growth and development of cells, promote spiral down premature aging, or may cause many other heavy damages by intoxicating the body (HA, 2010).

Many people consume network antioxidants - vitamin C, vitamin E, lipoic acid, coenzyme Q10, glutathione, etc because they want to look and feel younger 
DOI: 10.14807/ijmp.v10i6.932

(BUZEA, 2015; PETRESCU, 2015). Keeping antioxidant use -ie keeping free radicals in check can be one of the most effective ways to slow the aging process. Antioxidants network (a network of special antioxidants) work together in the body. Only five are considered the network antioxidants: Vitamin C, Vitamin E, lipoic acid, coenzyme Q10, and glutathione. Vitamin C and E are not produced by our body but must be obtained through food (ABDUL-RAZZAK, 2012; AHMED, 2011; AJITH, 2009; ATASAYAR, 2009; BABAEV, 2010; BUZEA, 2015).

When an antioxidant encounter a free radical, the radical is automatically joined to antioxidant molecular structure (EL-GENDY, 2009; ENSTROM, 2014). Antioxidant becomes a new type of free radical, harmless. This will exempt cells and tissue destructive action of a radically freely got out of control. What really makes the network of antioxidants to be special is that they can "recycle" or regenerate after they were loosened a radically free, widening and more power. For example: When Vitamin $C$ triggers a radically free it becomes weak free radical in the process.

This anti-oxidant can be recycled in the form of vitamin C. As an anti- oxidant network saves him on the other side, the cycle continues by making sure that the body will keep the correct balance of the antioxidants. This particular scenario - the antioxidant meets a free radical - it takes it, becomes a free radical friend - is recycled for another antioxidant network - occurs repeatedly in the body, in the blink of an eye.

Research has estimated that the number knocks oxidative degradation administered daily DNA in each cell is 10,000 and if this figure is multiplied by the millions of cells in the body can be understood the scale of such processes in the human body. Each antioxidant has a unique niche in the cell; for example in the areas of aqueous cell or in the blood, which consists primarily of water, they will act only vitamin $C$ and glutathione. Vitamin $C$ prevents skin cancer, guarding DNA of threat-free radicals. In normal amounts, Vitamin C provides beautiful skin (BUZEA, 2015; PETRESCU, 2015).

Vitamin $C$ is essential for collagen production cellular glue that holds the body bound and keeps skin young and supple. Vitamin $C$ protects the body against health problems especially in the elderly. Vitamin $C$ is considered the center of the 
INDEPENDENT JOURNAL OF MANAGEMENT \& PRODUCTION (IJM\&P)

http://Www.ijmp.jor.br

v. 10, n. 6, November-December 2019

ISSN: 2236-269X

DOI: 10.14807/ijmp.v10i6.932

antioxidant network, because of the connection between fat-soluble antioxidants and the water soluble. Vitamin $\mathrm{C}$ is important for reloading a fat-soluble vitamin $\mathrm{E}$; when it becomes a free radical, it best meets function. Vitamin C (ascorbic acid) is found in the following foods: citrus, green peppers, broccoli, blueberries, strawberries, tomatoes, cabbage (BUZEA, 2015; PETRESCU, 2015).

The daily minimum requirement of Vitamin $C$ at tissues and cells level for a healthy man is $90 \mathrm{mg} /$ day for men, $75 \mathrm{mg} /$ day women, $100 \mathrm{mg} /$ day smokers (PETRESCU, 2015). But always need a bigger tank because these amounts could reach all tissues and cells of a healthy organism: about 500-1000 mg/day. When the body is disturbed or ill, quantities needed to repair cells, are much higher 5000- $10000 \mathrm{mg} /$ day. Whenever it is preferable to get our daily requirement of vitamin $\mathrm{C}$ only from food. But in tough conditions, when there is a diagnosed disorder or disease, the body having really need large amounts, must intervene urgently with high amounts of vitamin $\mathrm{C}$ synthesized.

Canada's variety 2 killer, just behind cancer, is heart disease (HANSEN, 2014). It's the variety one cause of hospitalization and the price to the Canadian economy is staggering at $\$ 18.5$ billion per year! What is the first sign of a heart attack? The first sign in those situations means death. Minimum 70 percent of the heart attacks take place in people with vas blockages that don't seem to be detectable by roentgenogram the foremost relied upon method of assessment used today. On the other hand, more than $50 \%$ of people with a heart attack had normal cholesterol and $33 \%$ had no risk factors for cardiovascular diseases.

The natural treatments are made with individualized schemes to avoid heart disease. Important and needed first step is to determine the health situation. These assessments include blood and urine laboratory testing. Computerized assessment measures the stiffness of the major artery and the aorta. Aortic stiffness increases blood pressure and puts a strain on your heart. Moreover the heart frequency variability (which is an important indicator of the stress of the heart) is also measured (HANSEN, 2014).

Heart diseases prevention studies indicate that $93 \%$ of patients can control their blood pressure with diet alone by consuming more vegetables and fruits and salt reducing. Studies, however, show that only $38 \%$ of patients were able to 
INDEPENDENT JOURNAL OF MANAGEMENT \& PRODUCTION (IJM\&P)

http://Www.ijmp.jor.br

v. 10, n. 6, November - December 2019

ISSN: 2236-269X

DOI: 10.14807/ijmp.v10i6.932

keep this regimen. Weight control also prevents heart disease but like diet, they are hard to keep up. In these situations, medical treatment becomes a necessity.

Dr. Linus Pauling, Ph.D., won 2 Nobel prizes in medication and with Dr. M. Rath, M.D., established a cure for heart disease and a way to prevent it (RATH, 1990; RATH, 2003). They used high doses of aliment $C$ to strengthen the walls of blood vessels and stop the injury or breakdown of the walls that results in plaque built up, and narrowing of the blood vessels. They additionally used high doses of essential amino acid, AN amino acid, to stop the excessive build-up of plaque on the vessel walls. Taken along, vitamin $C$ and lysine are clinically effective. Dr. Robert Cathcart, M.D. treated over 20,000 patients without one case of cardiopathy developing (YILMAZ, 2006).

Dr. U. Ravnskov, M.D., a great authority in the cholesterol theory, say that all drugs to lowering cholesterol are very dangerous for our health and can shorten our life. All these drugs are action by inhibiting the body's innate ability to produce its own cholesterol. When one blocks the own cholesterol production it is creating significant complications on body health. Generally, cholesterol is an important life element for our liver, skin, for brain health, for the heart, etc. which are making the body's hormones, being particularly important when we age. When the hormone levels decrease our bodies respond with increased levels of cholesterol to supply the basic elements to raise our hormones levels (RAVNSKOV, 2009).

Meanwhile, the world experts in natural medicine claim high cholesterol as a great risk factor, there are other factors contributing to the development of heart disease that is more significant. Thus with respect to heart disease, a more comprehensive approach is needed. Some experts from Harvard have found that inflammation is one of the major causes of heart diseases. Today one knows that measurement of blood levels by C-reactive protein (an inflammatory marker), inflammation is a critical indicator in need of investigation.

The need to reduce negative human cholesterol levels started from the need to reduce the risk of cardiac or cerebrovascular accident. Natural medicines have today already a known history of success in preventing and especially treatment of heart disease, offering some alternative safe and effective treatments to classic 
INDEPENDENT JOURNAL OF MANAGEMENT \& PRODUCTION (IJM\&P)

http://Www.ijmp.jor.br

v. 10, n. 6, November-December 2019

ISSN: 2236-269X

DOI: 10.14807/ijmp.v10i6.932

pills (which after all are just drugs that do more harm to the body than good, dropping more the good cholesterol needed to the body).

Realistically most common sign of a heart attack is sudden death, unfortunately. Who survived such an attack, however, it was the subject of multiple and difficult tested, treated with a lot of chemical drugs and perhaps, unfortunately, has had to deregulate and one or more surgeries to control the disease. If in some extreme cases surgery and drugs are absolutely necessary today, in most cases they can be replaced by natural methods of treatment (alternative treatments) or when the disease is early (here the prevention can play an important role) or in situations the inflammation did not exceed certain limits.

The alternative (natural) medicine has today more effective and noninvasive treatment options. Therapy Pauling with lysine (an amino acid) and high doses of vitamin C, already has a history officially recognized treatments successful in situations where the disease was early (preventive), and in difficult cases of some patients who already had suffered at least one attack stroke or heart, with one or multiple surgeries, and heavy chemical treatments. Chelation therapy with intravenous injections consisting of an essential amino acid that removes heavy metals from the body has a success rate globally certified $87 \%$.

Another intravenous therapy, plaques, became a primary treatment for heart disease due to its ability to reduce plaque deposited in the arteries. These alternative treatments are for those with heart failure who can cause fatigue, shortness of breath, angina, and numbness in the limbs.

Existing inflammation in the blood has been unanimously identified as a major cause of heart disease and C-reactive protein (which is measured by a simple blood test) can donate valuable information regarding your risk of a heart attack.

An oral or intravenous medication natural can be used to reduce inflammation. Homocysteine and lipoprotein levels can analyze and give useful information on identifying the risk of blood clots. Testing Vital Signs provides a measure of the health of the heart as a score that can identify the health of the heart, specifically the aorta (the major artery). This last test computerized noninvasive blood flow also assesses the state of stress and nervous system learned about heart. 
INDEPENDENT JOURNAL OF MANAGEMENT \& PRODUCTION (IJM\&P)

http://Www.ijmp.jor.br

v. 10, n. 6, November-December 2019

ISSN: 2236-269X

DOI: 10.14807/ijmp.v10i6.932

In 1953, Dr. G. C. Willis, M.D., (a Canadian doctor) first formulated the principle that all cardiovascular diseases are linked to a deficiency of vitamin $\mathrm{C}$ (ascorbic acid) in the body. He found that plaques and inflammation occurring in the blood of patients were due to deficiency of vitamin $C$ in the body. Based on the idea already known that humans can't synthesize their own vitamin $C$ as they do generally animals is needed in many situations a filler daily vitamin $C$ in the body, either naturally (from food) or synthetic (when required doses are higher) (WILLIS, 1953; WILLIS, 1954; WILLIS, 1957).

In the 1980s, medical research led to the theory that heart disease starts with a fracture (or stress) produced in the arterial wall. The human body defends itself by producing a single in liver lipoprotein (a) stored as plaque in order to repair the damaged artery wall (These materials they gave a Nobel prize in medicine in 1985). The theory was then supported by German researchers, led by Dr. Beisiegel, which examined postmortem plaques and found only lipoprotein (a) but did not found and cholesterol considered "bad" (LDL cholesterol). Pauling and Rath have understood then that lack of vitamin C (which can't be manufactured by the liver) force liver to produces and uses instead of vitamin $C$ lipoprotein (a) for the reconstruction of the broken blood vessels.

That was understood that chronic heart disease represents only a consequence of chronic scurvy (lack of vitamin C prolonged). The liver produces and stores in its place the plaque to repair the tissue absented. But this thread (reserve) has no elasticity and superior properties of fabrics produced normally with the help of vitamin $\mathrm{C}$. On the other hand, needed reconstruction plaque behaves as a concrete, depositing it in large quantities and obstructing the arteries.

Alternative medicine, herbal, has made available to patients (over time) more effective treatment options therapies used varying in function on the specificity and seriousness of the case. One way general treatment was initiated and then generalized in 1989 (after many successful experiments, clinical and then patented in 1994 in the US) by Dr. Linus Pauling, Ph.D., and Dr. Mathias Roth, MD, the treatment being known as "Pauling Therapy" (RATH, 1990; RATH, 2003).

Some researchers of the University of California reports that patients taking a daily minimum of 500 milligrams of vitamin $\mathrm{C}$ as a dietary supplement, managed 
INDEPENDENT JOURNAL OF MANAGEMENT \& PRODUCTION (IJM\&P)

http://Www.ijmp.jor.br

v. 10, n. 6, November - December 2019

ISSN: 2236-269X

DOI: 10.14807/ijmp.v10i6.932

everyone to drop naturally (this way) C-reactive protein (CRP) in the blood by 24 percent after about two months of sustained treatment. More recent studies suggest that CRP is a far better predictor of heart disease than cholesterol. C-reactive protein is a real indicator of inflammation in the blood and body, and there is today evidence that large chronic inflammation generates both the risk of heart disease or the occurrence of a stroke, but also an increased risk of producing a shape diabetes, Alzheimer's disease or other serious diseases (Dr. Gladys Block, UC Berkeley professor) (Gladys).

Dr. James Enstrom (University of California) investigated the benefits of the addition of $300 \mathrm{mg}$ vitamin $\mathrm{C}$ daily (food supplement) on 11,000 people in over ten years. He showed that this additional minimal amount administered daily $(300 \mathrm{mg}$ vitamin C), reduces the risk of heart disease by $50 \%$ in men and $40 \%$ in women (ENSTROM, 2014).

G.C. Willis doctor found that all those who consumed $1,500 \mathrm{mg}$ daily dietary supplement of vitamin $\mathrm{C}$, within a year, managed to remove plaque from arteries, and those who did not receive the treatment with vitamin $C$ have suffered an increase of plaque (WILLIS, 1953; WILLIS, 1954; WILLIS, 1957).

Dr. Sydney Bush has developed a way to test the existence of plaque in the arteries by optometry (photo retina). He could track and assess accurately the existence and plaque thickness deposited in the arteries by this ingenious way of diagnosis. The method was devised in 2002 after being tested on more patients, some of whom were treated daily with vitamin $\mathrm{C}$. The method can accurately predict the amount of vitamin $\mathrm{C}$ present in an organism, and additional daily needs.

Vitamin C (ascorbic acid) contributes to a wide range of benefits. Vitamin $C$ is known to perform several critical functions within the body involving such as detoxification, tissue-building, strengthen the immune system, pain control, and control or kill pathogens. It is known to be helpful for wound and bone healing, healthy skin and eyes, fighting infections, stress management, toxic exposure, and repair damaged the tissue of all kinds.

Richard T. Lee, MD, led a team of researchers from Harvard Medical School, in order to test the 880 chemical compounds (all already authorized for use in humans in medicines, supplements, etc.) on their effect on stem cells embryo (in 
INDEPENDENT JOURNAL OF MANAGEMENT \& PRODUCTION (IJM\&P)

http://Www.ijmp.jor.br

v. 10, n. 6, November-December 2019

ISSN: 2236-269X

DOI: 10.14807/ijmp.v10i6.932

this case collected from mice). All stem cells used were initially treated to emit a certain color green when developed in heart muscle cells, and only one chemical issue (from all 880 tested) managed to promote stem cell activity, which is just vitamin C (Richard).

Vitamin C has been used in tandem with vitamin $\mathrm{K} 3$ in order to realize an auxiliary treatment against cancer, because vitamin $C$ is the main antioxidant independent, playing a key role in protecting healthy cells against oxidative stress. When vitamin $C$ is used in combination with other antioxidants such as glutathione and other drugs such as magnesium, sodium and optionally iodine, it can cause considerable damage to cancer cells, without affecting the healthy cells.

Dr. Sudhir Kurl of the University of Kuopio, Finland conducted a study of more than 2400 overweight patients who had high blood pressure. It was demonstrated that a low level of vitamin $C$ made the risk of a stroke three times greater (KUNUTSOR, 2016).

If we want to find out more we may read 'Why Animals Don't Get Heart Attacks - But People Do!' by Dr. Matthias Rath (RATH, 1990; RATH, 2003).

Our ancestors have undergone a genetic mutation about 50 million years ago, the mutation that caused the final enzyme in the liver vitamin $C$ synthesis to disappear. For this reason, the human liver has not made it and was so ordinary. Principal missing enzyme is called GLO (gulonolactone oxidase). In animals, it appears and fulfills its function of vitamin $C$ production in the liver. However, there are some animals such as gorillas, chimpanzees, and orangutans which share the same mutation GLO and also can't produce vitamin C. These primates can also have cardiovascular disease, if their food do not donate them enough vitamin C. Except for humans and primates, all other animals have the three enzymes in the liver which can synthesize vitamin $C$ from glucose (a simple sugar).

Another exception is the guinea pig (guinea pig, a rodent). Guinea pig, for reasons not fully understood yet suffered the same genetic mutation as people, and he was deprived of GLO enzyme. However, this is extremely advantageous for us humans as guinea pig can be used in various experiments needed to study the mechanisms that generate human disease. The gorillas, chimpanzees, and orangutans which lack the ability to synthesize vitamin $C$ also get heart disease. 
DOI: 10.14807/ijmp.v10i6.932

Steve Hickey and Hilary Roberts have shown in their book and made the statement "Vitamin C and Tocotrienols can reverse coronary artery disease" (Hickey, 2007).

\section{RESULTS AND DISCUSSION}

According to the Private Health Research Laboratory, hypertension is the most dangerous disease in the 21st century. It sheds more people than cancer (CHOUDHURY; GREENE, 2018; CHOUDHURY, 2018), AIDS, hepatitis, diabetes, and tobacco taken together!

List of pathologies associated with high blood pressure when the disease is not cured on time.

Stage 1. At first, blood pressure increases occasionally, but at the same time, the first symptoms of hypertension are already present:

- headache,

- Sleep disorder,

- feeling tired,

- palpitations,

- $\quad$ ringing in the ears,

- feeling unmotivated by anxiety,

- shaking,

- irrationality without reason.

As a rule, patients do not hurry to go to the doctor, while the dishes and the heart begin to destroy.

Stage 2. The tension is growing more often and rarely returns to normal values. The patient may experience severe eye pressure, memory disturbances, swelling, abnormal working capacity, atherosclerosis, and decreased vision. These symptoms indicate that the disease has gone too far. If the necessary steps are not taken at this stage, the person will completely waste their health.

Stage 3. There are irreversible processes. Blood flow disturbances and high blood pressure lead to the occurrence of many associated diseases: nephrosclerosis, 
DOI: 10.14807/ijmp.v10i6.932

renal failure, blindness, angina pectoris, diabetes mellitus, Alzheimer's disease, etc.

Stage 4. The blood vessels are so thin that internal pressure is ruptured at high pressure. If a bowel breaks out of the muscle, a heart attack occurs in the brain - stroke. Even if he does not die, he will remain invalid all his life.

Treatments for lowering blood pressure are multiple, with a very high diversity depending on the patient, the doctor, the situation. However, it may be generalized as a preventive, or adjuvant, use of dietary supplements containing vitamin $\mathrm{C}$. It can be taken naturally from cabbage, grapes, citrus, berries, tomatoes, onions, broccoli, strawberries, but it is often necessary daily synthetic supplements to be also consumed as needed.

As adjuvant treatments, acupuncture can also be used, or more pleasant and simpler, the homeopathy well applied by an experienced specialist.

Regular cleaning of blood vessels of depositions that take place inside them also has the beneficial effect of prolonging life as well as installing a well-being on the applicant patient.

But this is just the first step in the anti-aging measures to be taken.

\section{CONCLUSIONS}

The highly circulating system needs permanent maintenance. Selfmaintenance is done through various physiological mechanisms tightly linked to each other, including the lymphatic, digestive, renal, lung, nervous, glandular system ... It is not possible to completely separate the physiology of a system from the other adjacent systems because they all work synergistically, being permanently controlled by the central and peripheral nervous system.

Treatments for lowering blood pressure are multiple, with a very high diversity depending on the patient, the doctor, the situation. However, it may be generalized as a preventive, or adjuvant, use of dietary supplements containing vitamin $\mathrm{C}$. It can be taken naturally from cabbage, grapes, citrus, berries, tomatoes, onions, broccoli, strawberries, but it is often necessary daily synthetic supplements to be also consumed as needed.

As adjuvant treatments, acupuncture can also be used, or more pleasant and simpler, the homeopathy well applied by an experienced specialist. 
INDEPENDENT JOURNAL OF MANAGEMENT \& PRODUCTION (IJM\&P)

http://Www.ijmp.jor.br

v. 10, n. 6, November-December 2019

ISSN: 2236-269X

DOI: 10.14807/ijmp.v10i6.932

Regular cleaning of blood vessels of depositions that take place inside them also has the beneficial effect of prolonging life as well as installing a well-being on the applicant patient.

But this is just the first step in the anti-aging measures to be taken.

\section{ACKNOWLEDGEMENT}

This text was acknowledged and appreciated by Dr. Veturia CHIROIU Honorific member of Technical Sciences Academy of Romania (ASTR) PhD supervisor in Mechanical Engineering.

\section{REFERENCES}

ABDUL-RAZZAK K., ALZOUBI K., ABDO S., HANANEH W., (2012) High-dose vitamin C: Does it exacerbate the effect of psychosocial stress on liver? Biochemical and histological study, Experimental and Toxicologic Pathology, v. 64 , n. 4, p. 367-371

AHMED, E.; OMAR, H.; ELGHAFFAR, S.; RAGB, S.; NASSER, A. (2011) The antioxidant activity of Vitamin C, DPPD and I-cysteine against Cisplatin-induced testicular oxidative damage in rats, Food and Chemical Toxicology, v. 49, n. 5, p. $1115-1121$

AJITH T. A.; ABHISHEK, G.; ROSHNY, D.; SUDHEESH, N. P. (2009) Cosupplementation of single and multi doses of vitamins $C$ and $E$ ameliorates cisplatin-induced acute renal failure in mice, Experimental and Toxicologic Pathology, v. 61, n. 1, p. 565-571

ALEXANDER, C. A.; WANG, L. (2018) Healthcare Driven by Big Data Analytics. Am. J. Eng. Applied Sci., v. 11, n. 3, p. 1154-1163. DOI: 10.3844/ajeassp.2018.1154.1163

ALJOHANI, A.; DESAI, S. ( 2018) 3D Printing of Porous Scaffolds for Medical Applications. Am. J. Eng. Applied Sci., v. 11, n. 3, p. 1076-1085. DOI: 10.3844/ajeassp.2018.1076.1085

APICELLA, A.; AVERSA, R.; PETRESCU, F. I. T. 2018a. Hybrid CeramoPolymeric Nano-Diamond Composites. Am. J. Eng. Applied Sci., v. 11, n. 2, p. 766-782. DOI: 10.3844/ajeassp.2018.766.782

APICELLA, A.; AVERSA, R.; PETRESCU, F. I. T. 2018b. Biomechanically Inspired Machines, Driven by Muscle Like Acting NiTi Alloys. Am. J. Eng. Applied Sci., v. 11, n. 2, p. 809-829. DOI: 10.3844/ajeassp.2018.809.829

APICELLA, A.; AVERSA, R.; TAMBURRINO, F.; PETRESCU, F. I. T. (2018c) About the Internal Structure of a Bone and its Functional Role. Am. J. Eng.

Applied Sci., v. 11, n. 2, p. 914-931. DOI: 10.3844/ajeassp.2018.914.931

ARMAH, S. K. (2018) Stress Analysis of an Artificial Human Elbow Joint:

Application of Finite Element Analysis. Am. J. Eng. Applied Sci., v. 11, n. 1, p. 1-18. DOI: 10.3844/ajeassp.2018.1.18 
ATASAYAR, S.; GÜRER-ORHAN, H.; GÜREL, B.; GIRGIN, G.; ÖZGÜNES, H. (2009) Preventive effect of aminoguanidine compared to vitamin $E$ and $C$ on cisplatin- induced nephrotoxicity in rats, Experimental and Toxicologic Pathology, v. 61, n. 1, p. 23-32

AVERSA, R.; APICELLA, A.; TAMBURRINO, F.; PETRESCU, F. I. T. (2018a) Mechanically Stimulated Osteoblast Cells Growth. Am. J. Eng. Applied Sci., v. 11, n. 2, p. 1023-1036. DOI: 10.3844/ajeassp.2018.1023.1036

AVERSA, R.; PARCESEPE, D . ; TAMBURRINO, F .; APICELLA, A.; PETRESCU, F. I. T. (2018b) Cold Crystallization Behavior of a Zr44-Ti11-Cu10Ni10- Be25 Metal Glassy Alloy. Am. J. Eng. Applied Sci., v. 11, n. 2, p. 10051022. DOI: $10.3844 / a j e a s s p .2018 .1005 .1022$

AVERSA, R.; PETRESCU, R. V.; A. APICELLA, A.; PETRESCU, F. I. T. ( 2017a) Nano-diamond hybrid materials for structural biomedical application. Am.

J. Biochem. Biotechnol., n. 13, p. 34-41. DOI: 10.3844/ajbbsp.2017.34.41

AVERSA, R.; PARCESEPE, D.; PETRESCU, R. V.; BERTO, F.; CHEN, G. (2017b) Process ability of bulk metallic glasses. Am. J. Applied Sci., n. 14, p. 294-301. DOI: 10.3844/ajassp.2017.294.301

AVERSA, R.; PETRESCU, F. I. T.; PETRESCU, R. V.; APICELLA, A. (2016a) Biomimetic FEA bone modeling for customized hybrid biological prostheses development. Am. J. Applied Sci., n. 13, p. 1060-1067. DOI: 10.3844/ajassp.2016.1060.1067

AVERSA, R.; PARCESEPE, D.; PETRESCU, R. V.; CHEN, G.; PETRESCU, F. I. T. (2016b) Glassy amorphous metal injection molded induced morphological defects. Am. J. Applied Sci., n. 13, p. 1476-1482. DOI: 10.3844/ajassp.2016.1476.1482

AVERSA, R.; TAMBURRINO, F.; PETRESCU, R. V.; PETRESCU, F. I. T.; ARTUR, M. (2016c) Biomechanically inspired shape memory effect machines driven by muscle like acting NiTi alloys. Am. J. Applied Sci., n. 13, p. 1264-1271. DOI: 10.3844/ajassp.2016.1264.1271

AVERSA, R.; BUZEA, E. M.; PETRESCU, R. V.; APICELLA, A.; NEACSA, M. (2016d) Present a mechatronic system having able to determine the concentration of carotenoids. Am. J. Eng. Applied Sci., n. 9, p. 1106-1111. DOI: 10.3844/ajeassp.2016.1106.1111

AVERSA, R.; PETRESCU, R. V.; R. SORRENTINO, PETRESCU, F. I. T.; APICELLA, A. (2016e) Hybrid ceramo-polymeric nanocomposite for biomimetic scaffolds design and preparation. Am. J. Eng. Applied Sci., n. 9, p. 1096-1105. DOI: 10.3844/ajeassp.2016.1096.1105

AVERSA, R.; PERROTTA, V.; PETRESCU, R. V.; MISIANO, C.; PETRESCU, F. I. T. (2016f) From structural colors to super-hydrophobicity and achromatic transparent protective coatings: Ion plating plasma assisted $\mathrm{TiO}_{2}$ and $\mathrm{SiO} 2$ nanofilm deposition. Am. J. Eng. Applied Sci., n. 9, p. 1037-1045. DOI: 10.3844/ajeassp.2016.1037.1045

AVERSA, R.; PETRESCU, R. V.; PETRESCU, F. I. T.; APICELLA, A. (2016g) Biomimetic and evolutionary design driven innovation in sustainable products development. Am. J. Eng. Applied Sci., n. 9, p. 1027-1036. DOI: 
INDEPENDENT JOURNAL OF MANAGEMENT \& PRODUCTION (IJM\&P)

http://Www.ijmp.jor.br

v. 10, n. 6, November-December 2019

ISSN: 2236-269X

DOI: 10.14807/ijmp.v10i6.932

10.3844/ajeassp.2016.1027.1036

AVERSA, R.; PETRESCU, R. V.; APICELlA, A.; PETRESCU, F. I. T. (2016h) Mitochondria are naturally micro robots - a review. Am. J. Eng. Applied Sci., n . 9, p. 991-1002. DOI: 10.3844/ajeassp.2016.991.1002

AVERSA, R.; PETRESCU, R. V.; APICELLA, A.; PETRESCU, F. I. T. (2016i) We are addicted to vitamins $C$ and E-A review. Am. J. Eng. Applied Sci., n. 9, p. 10031018. DOI: 10.3844/ajeassp.2016.1003.1018

AVERSA, R.; PETRESCU, R. V.; APICELlA, A.; PETRESCU, F. I. T. (2016j) Physiologic human fluids and swelling behavior of hydrophilic biocompatible hybrid ceramo-polymeric materials. Am. J. Eng. Applied Sci., n. 9, p. 962-972. DOI: 10.3844/ajeassp.2016.962.972

AVERSA, R.; PETRESCU, R. V.; APICELlA, A.; PETRESCU, F. I. T. (2016k) One can slow down the aging through antioxidants. Am. J. Eng. Applied Sci., n. 9, p. 1112-1126. DOI: 10.3844/ajeassp.2016.1112.1126

AVERSA, R.; PETRESCU, R. V.; APICELLA, A.; PETRESCU, F. I. T. (2016I) About homeopathy or «Similia Similibus Curentur». Am. J. Eng. Applied Sci., v . 9, p. 1164-1172. DOI: 10.3844/ajeassp.2016.1164.1172

AVERSA, R.; PETRESCU, R. V.; APICELlA, A.; PETRESCU, F. I. T. (2016m) The basic elements of life's. Am. J. Eng. Applied Sci., n. 9, p. 1189-1197. DOI: 10.3844/ajeassp.2016.1189.1197

AVERSA, R.; PETREsCU, F. I. T.; PETRESCU, R. V.; APICELLA, A. (2016n) Flexible stem trabecular prostheses. Am. J. Eng. Applied Sci., n. 9, p. 12131221. DOI: 10.3844 /ajeassp.2016.1213.122

BABAEV, V. R.; LI, L.; SHAH, S.; FAZIO, S.; LINTON, M. F.; MAY, J. M. (2010) Combined Vitamin C and Vitamin E Deficiency Worsens Early Atherosclerosis in ApoE-Deficient Mice, Arteriosclerosis, thrombosis, and vascular biology, $\mathrm{v}$. 30, n. 9, p. 1751-1757

BUZEA, E.; PETRESCU, F. L.; NĂNUT, L.; NAN, C.; NEACŞA, M., (2015) Mechatronic System to Determine the Concentration of Carotenoids, Analele Univers. Craiova Biologie Horticultura Tehn. Prel. Prod. Agr. Ing. Med., v. 20, n. 1, p. 371-376

CHOUDHURY, A.; GREENE, C. M. (2018) Identification of Cancer: Mesothelioma's Disease Using Logistic Regression and Association Rule. Am. J. Eng. Applied Sci., v. 11, n. 4.

CHOUDHURY, A. (2018) Evaluating Patient Readmission Risk: A Predictive Analytics Approach. Am. J. Eng. Applied Sci., v. 11, n. 4.

COVIC, M.; COVIC, A.; TATOMIR, P. G.; SEGALL, L. ( 2007) Manual de nefrologie, Polirom Publisher, 448 pages, ISBN: 978-973-46-0672-6

EL-GENDY, K. S.; ALY, N. M.; MAHMOUD, F. H.; KENAWY, A.; EL-SEBAE, A. K. (2009) The role of vitamin $C$ as antioxidant in protection of oxidative stress induced by imidacloprid, Food Chem Toxicol, v. 48, n. 1, p. 215-221

ENSTROM, J. (2014) Food and You: Feeding The World With Modern Agricultural Biotechnology, American Council on Science and Health. Retrieved from: http://acsh.org/2014/03/food-feeding-world-modern-agricultural-biotechnology- 
INDEPENDENT JOURNAL OF MANAGEMENT \& PRODUCTION (IJM\&P)

http://www.ijmp.jor.br

v. 10, n. 6, November-December 2019

ISSN: 2236-269X

DOI: 10.14807/ijmp.v10i6.932

2/

GLADYS BLOCK, Retrieved from: http://sph.berkeley.edu/gladys-block

HA, H-L.; SHIN, H-J.; FEITELSON, M. A.; YU, D-Y. (2010) Oxidative stress and antioxidants in hepatic pathogenesis, World Journal of

Gastroenterology: WJG., v. 16, n. 48, p. 6035-6043

HANSEN, S. N.; TVEDEN-NYBORG, P.; LYKKESFELDT, J. (2014) Does vitamin C deficiency affect cognitive development and function? Nutrients., v. 6, n. 9, p. 3818-3846

HICKEY, S.; ROBERTS, H. (2007) The Cancer Breakthrough, 96 pages, ISBN 9781430323006

KUNUTSOR, S.; KURL, S.; ZACCARDI, F.; LAUKKANEN, J. (2016) Baseline and long-term fibrinogen levels and risk of sudden cardiac death: A new prospective study and meta-analysis, Atherosclerosis, n. 245, p. 171-180

MARQUETTI, I.; DESAI, S. (2018) Adsorption Behavior of Bone Morphogenetic Protein-2 on a Graphite Substrate for Biomedical Applications. Am. J. Eng.

Applied Sci., v. 11, n. 2, p. 1037-1044. DOI: 10.3844/ajeassp.2018.1037.1044

PETRESCU, F. L.; BUZEA, E.; NĂNUT, L.; NEACŞA, M.; NAN, C. (2015) The

Role of Antioxidants in Slowing Aging of Skin in a Human, Analele Univers.

Craiova Biologie Horticultura Tehn. Prel. Prod. Agr. Ing. Med., v. 20, n. 1, p. 567574

RATH, M. AND PAULING L., (1990) Hypothesis: lipoprotein(a) is a surrogate for ascorbate, Proc Natl Acad Sci USA, v. 87, n. 16, p. 6204-6207

RATH, M. (2003) Why Animals Don't Get Heart Attacks... but People Do!, MR Publishing, Inc., Fremont, CA, USA, Edition: 4th, Fourth, 319 pages, ISBN 13:

978-0-9679546-8-4

RAVNSKOV, U. (2009) Fat and Cholesterol are Good for You, 244 pages, Publisher: GB Publishing, English, ISBN-13: 978-9197555388

TAMBURRINO, F.; APICELLA, A.; AVERSA, R.; PETRESCU, F. I. T. (2018) Advanced Manufacturing for Novel Materials in Industrial Design Applications.

Am. J. Eng. Applied Sci., v. 11, n. 2, p. 932-972. DOI:

10.3844/ajeassp.2018.932.972

WILK, J.; SANDERS, G.; MARKS, S.; PAOLICELLI, S. A.; DICAPRIO, M.;

BUCINELL, R. (2017) The Optimization of a Porous Ti6Al4V Bone Construct

Using Additive Manufacturing. Am. J. Eng. Applied Sci., v. 10, n. 1, p. 13-19.

DOI: 10.3844/ajeassp.2017.13.19

WILLIS, G. C. (1953) An experimental study of the intimal ground substance in atherosclerosis, Can Med Assoc J., n. 69, p. 17-22

WILLIS, G. C.; LIGHT A. W.; GOW W.S. (1954) Serial Arteriography in

Atherosclerosis in Human Beings, Can Med Assoc J., n. 71, p. :562-568

WILLIS, G. C. (1957) The reversibility of atherosclerosis, Can Med Assoc J., n. 77, p. $106-108$

W.SITE OF RICHARD T. LEE, MD. Retrieved from:

http://hsci.harvard.edu/people/richard-lee-md 